\title{
Fatty Acid Composition and Hedonic Ratings of Meat from Light Lambs of Leccese Breed in Relation to Slaughter Age
}

\author{
Angela Gabriella D’Alessandro ${ }^{\#}$, Maria Selvaggi ${ }^{*}$, Giovanni Martemucci ${ }^{\#}$

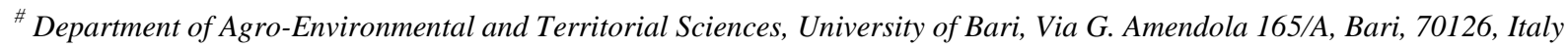 \\ E-mail: angelagabriella.dalessandro@uniba.it \\ * Department of DETO, University of Bari,Valenzan,70010, Italy \\ E-mail: maria.selvaggi@uniba.it
}

\begin{abstract}
Twenty lambs from Leccese local breed were used to investigate the effect of two slaughter ages (45 vs $60 \mathrm{~d})$ on fatty acid composition and hedonic ratings of meat. The lambs, born as singles in spring, were subdivided into two groups (n. 10) corresponding to the slaughter ages of 45 and $60 \mathrm{~d}$. The animals received their mother's milk and a supplementation of hay and concentrate from 30 d to slaughter. The increase to $60 \mathrm{~d}$ of slaughter age resulted in higher proportion of lauric acid $(\mathrm{C12:0}$; $P<0.05)$, pentadecanoic acid $(C 15: 0 ; P<0.01)$ and conjugated linoleic acid (CLA; $P<0.05)$, and lower proportion of stearic acid $(C 18: 0 ; P<0.05)$ and linoleic acid $(C 20: 3$ n-6; $P<0.05)$. Using a none-point hedonic scale, consumer test showed that meat from lambs slaughtered at $60 \mathrm{~d}$ received a higher hedonic scores $(P<0.01)$ as well as higher scores for tenderness $(P<0.05)$, flavour $(P<0.05)$, and juiciness $(P<0.001)$ than meat from lambs slaughtered at $45 \mathrm{~d}$. These findings might be useful to characterise lamb meat of local origin in relation to its nutritional traits and market perspectives connected to consumer acceptability.
\end{abstract}

Keywords — Light lamb meat; age; slaughter season; fatty acid profile; consumer.

\section{INTRODUCTION}

Meat of lamb obtained from local breeds are worthy of attention in terms of sustainable farming systems, as they can minimise the use of chemicals and allows to an environment friendly production, a safer food, and a higher commercial value of the product also strengthening its link with the territory of origin.

Leccese is a dairy autochthonous breed of southern Italy which is well adapted to the agroclimatic conditions and vegetation of the region. It is characterized by medium size (65 and $45 \mathrm{~kg}$ as average mature weight for males and females), white long fleece, black face and limbs black or speckled.

This breed, in addition to the production of milk (on average $150 \mathrm{~kg}$ in 130-180 days of lactation), is devoted to the production of meat from suckling lambs with light carcasses of 8 to $12 \mathrm{~kg}$. Several quality traits of meat including nutritional value and organoleptic characteristics are largely related to its fatty acid composition [1,2, which are influenced, among the multiple interacting factors, by the breed and the age/weight at slaughter of the animals $[3,4.5]$.
The aim of the study was to evaluate the fatty acid composition and hedonic ratings of meat of Leccese lambs in relation to two slaughter ages.

\section{MATERIALS AND METHODS}

The trial was carried out in spring in southern Italy using twenty male lambs, born as singles, of Leccese breed. At birth, the lambs were allocated to two experimental groups (n. 10), corresponding to the experimental slaughter ages of 45 and 60 days. The lambs received maternal milk and a supplementation of hay and commercial concentrate from 30 days to slaughter. At slaughter, samples of longissimus muscle were taken after $24 \mathrm{~h}$ of refrigeration $\left(2\right.$ to $\left.4{ }^{\circ} \mathrm{C}\right)$, vacuum-packed and stored at $-20{ }^{\circ} \mathrm{C}$ until analyses. Lipids were extracted according to the methodology described by Folch et al. [6]. Fatty acids were quantified using a Chrompack CP 9000 gas chromatograph, equipped with a capillary column in silicate glass $(50 \mathrm{~m} \times 0.25 \mathrm{~mm}$ internal diameter and $0.2 \mu \mathrm{m}$ film thickness; Phenomenex, Torrance, CA, USA). Temperature programme was: $135{ }^{\circ} \mathrm{C}$ for $7 \mathrm{~min}$, increase of temperature of $4{ }^{\circ} \mathrm{C}$ a minute to arrive at $210{ }^{\circ} \mathrm{C}$. The atherogenic (AI) and thrombogenic (TI) indexes [7] were calculated. 
A sensory analysis was performed on the pelvic limb from the right sides of each carcass of the lambs. After $5 \mathrm{~d}$ of ageing, sensory quality of meat was evaluated by habitual consumers (n. 8 males and n. 12 females), from 25 to 62 years in age. Each panellist evaluated the meat samples on its intrinsic characteristics such as the tenderness, juiciness, flavour and overall acceptability, according to an unstructured line scale ranging from 1 ("very unpleasant") to 9 ("very pleasant") [8].

The data were analyzed using the GLM procedure of SAS [9]. Means were compared using the t test.

\section{RESULTS AND DISCUSSION}

The total SFA proportion of the lamb meat was unaffected by the slaughter age ( $\mathrm{P}>0.05$; Table I).Considering the individual SFA, meat from the 45 days lambs resulted in a higher proportion of stearic acid $(\mathrm{C} 18: 0 ; \mathrm{P}<0.05)$, whereas the increase in slaughter age to 60 days showed higher contents of lauric $(\mathrm{C} 12: 0 ; \mathrm{P}<0.05)$ and pentadecanoic $(\mathrm{C} 15: 0$; $\mathrm{P}<0.01)$ acids.

Greater SFA, C12:0 and C14:0 values have been reported in meat from heavier lambs compared to lighter lambs [10]. In the present study, the limited differences found in the SFA profile between the two ages could be related to the similar slaughter weight observed in the two groups (data not shown).

Comparison of the experimental groups revealed no differences in MUFA content (Table II).

Total content of PUFA was not affected $(\mathrm{P}<0.05)$ by the slaughter age (Table III). However, in meat from lambs slaughtered at 45 days was higher $(\mathrm{P}<0.05) \mathrm{C} 20: 3 \mathrm{n}-6$, whereas meat from lambs slaughtered at 60 days showed the higher $(\mathrm{P}<0.05)$ content of total CLA and $\mathrm{C} 18: 2$ conj cis; Table III).

CLA is assumed to have great importance in the human diet due to its potential health benefits against several diseases [11,12,13,14,15] (Kritchevsky, 2003; Belury, 2003; Philpott and Ferguson, 2004; Gaullier et al., 2007), and oxidative stresses (Dielzer and Park, 2012).

The TI and AI did not differ in relation to the slaughter age of the lambs (Table III).

TABLE I

SATURATED FATTY ACID COMPOSITION (\% OF TOTAL FATTY ACIDS) OF INTRAMUSCULAR FAT IN CARCASSES OF LAMBS SLAUGHTERED AT 45 AND 60 DAY.

\begin{tabular}{|l|l|l|}
\hline \multicolumn{3}{|c|}{ Slaughter age of lambs } \\
\hline & $\mathbf{4 5}$ day & 60 day \\
\hline Total SFA $^{(1)}$ & 51.85 & 54.58 \\
\hline C10:0 & 0.41 & 0.54 \\
\hline C12:0 & $1.10 \mathrm{a}$ & $1.76 \mathrm{~b}$ \\
\hline C14:0 & 9.32 & $11.08 \mathrm{a}$ \\
\hline C15:0 & $0.71 \mathrm{~B}$ & $0.90 \mathrm{~A}$ \\
\hline C16:0 & 25.78 & 27.55 \\
\hline C17:0 & 0.99 & 1.06 \\
\hline C18:0 & $13.41 \mathrm{~b}$ & $11.57 \mathrm{a}$ \\
\hline C20:0 & 0.13 & 0.11 \\
\hline
\end{tabular}

(1) Saturated fatty acids

A, B: $\mathrm{P}<0.01$

a, b: $\mathrm{P}<0.05$
TABLE II

MONOUNSATURATED ATTY ACID COMPOSITION (\% OF TOTAL FATTY ACIDS) OF LONGISSIMUS LUMBORUM INTRAMUSCULAR FAT IN CARCASSES OF LAMB SLAUGHTERED AT 45 AND 60 DAY.

\begin{tabular}{|l|l|l|}
\hline \multicolumn{3}{|c|}{ Slaughter age of lambs } \\
\hline & $\mathbf{4 5}$ day & $\mathbf{6 0}$ day \\
\hline Total MUFA $^{(2)}$ & 39.19 & 36.55 \\
\hline $\mathrm{C} 14: 1$ & 0.19 & 0.21 \\
\hline $\mathrm{C} 15: 1$ & 0.24 & 0.24 \\
\hline $\mathrm{C} 16: 1$ & 1.61 & 1.92 \\
\hline $\mathrm{C} 17: 1$ & 0.47 & 0.57 \\
\hline $\mathrm{C} 18: 1$ & 36.53 & 33.49 \\
\hline $\mathrm{C} 18: 1 \mathrm{n}-7$ & 0.79 & 0.74 \\
\hline $\mathrm{C} 18: 1 \mathrm{n}-9$ trans & 0.44 & 0.39 \\
\hline $\mathrm{C} 18: 1 \mathrm{n}-9$ cis & 35.30 & 32.36 \\
\hline $\mathrm{C} 20: 1 \mathrm{n}-9$ & 0.10 & 0.08 \\
\hline $\mathrm{C} 22: 1 \mathrm{n}-9$ & 0.04 & 0.04 \\
\hline
\end{tabular}

(2) Monounsaturated fatty acids

TABLE III

POLYUNSATURATED FATTY ACID COMPOSITION (\% OF TOTAL FATTY ACIDS) AND ATHEROGENIC AND THROMBOGENIC INDICES OF INTRAMUSCULAR FAT IN CARCASSES OF LAMB SLAUGHTERED AT 45 AND 60 DAY

\begin{tabular}{|l|l|l|}
\hline \multicolumn{3}{|c|}{ Slaughter age of lambs } \\
\hline & $\mathbf{4 5}$ day & 60 day \\
\hline Total PUFA $^{(3)}$ & 9.09 & 8.91 \\
\hline C18:2 & 4.65 & 4.60 \\
\hline C 18:2 n-6 trans & 0.14 & 0.18 \\
\hline C 18:2 n-6 cis & 4.51 & 4.42 \\
\hline CLA & 1.07 a & $1.36 \mathrm{~b}$ \\
\hline C 18:2 conj trans & 0.05 & 0.05 \\
\hline C 18:2 conj cis & 1.02 a & $1.31 \mathrm{~b}$ \\
\hline C18:3 n-3 & 0.85 & 0.91 \\
\hline C18:3 n-6 & 0.15 & 0.16 \\
\hline C20:2 n-6 & 0.10 & 0.12 \\
\hline C20:3 n-3 & 1.27 & 0.99 \\
\hline C20:3 n-6 & 0.16 a & $0.08 \mathrm{~b}$ \\
\hline C20:4 n-6 & 0 & 0.01 \\
\hline C20:5 n-3 & 0.17 & 0.17 \\
\hline C21:5 n-3 & 0.05 & 0.07 \\
\hline C22:5 n-3 & 0.48 & 0.38 \\
\hline C22:5 n-6 & 0.03 & 0.02 \\
\hline C22:6 n-3 & 0.19 & 0.14 \\
\hline & & 1.73 \\
\hline AI ${ }^{(4)}$ & 1.39 & 1.71 \\
\hline TI ${ }^{(5)}$ & 1.50 & \\
\hline
\end{tabular}

(3) Polyunsaturated fatty acids

(4) Atherogenic index

(5) Thrombogenic index $\mathrm{a}, \mathrm{b}: \mathrm{P}<0.05$

Sensory attributes of meat are of great importance to consumers, producers and retailers. The mean values for the sensory characteristics are presented in Table IV. The meat from 60-day lambs received higher hedonic scores for tenderness $(\mathrm{P}<0.05)$, flavour $(\mathrm{P}<0.05)$, juiciness $(\mathrm{P}<0.01)$ and overall acceptability $(\mathrm{P}<0.01)$ than the meat from lambs slaughtered at 45 day. 
TABLE IV

THE SENSORY ANALYSIS (RATED ON A SCALE 1 TO 9) OF LAMBS MEAT IN RELATION TO SLAUGHTER WEIGHT (MEAN \pm SE).

\begin{tabular}{|l|l|l|}
\hline \multicolumn{3}{|c|}{ Slaughter age of lambs } \\
\hline Traits & 45 day & 60 day \\
\hline Tenderness & $7.4 \pm 1.0 \mathrm{a}$ & $8.1 \pm 0.8 \mathrm{~b}$ \\
\hline Flavour & $7.5 \pm 0.8 \mathrm{a}$ & $8.1 \pm 0.8 \mathrm{~b}$ \\
\hline Juiciness & $6.7 \pm 1.2 \mathrm{~A}$ & $8.1 \pm 0.7 \mathrm{~B}$ \\
\hline Overall acceptability & $7.4 \pm 1.0 \mathrm{~A}$ & $8.3 \pm 0.9 \mathrm{~B}$ \\
\hline
\end{tabular}

A, B: $\mathrm{P}<0.01$

a, b: $P<0.05$

Several factors are considered to be responsible for the flavour of the meat, such as age, genotype, and slaughter weight of the animals, carcass fatness level [16,17], and unsaturated fatty acids content [18]. In this study, the prevalent effect on the consumer evaluation of meat quality may be attributed to the age of the lambs. These differences are due to the development of the tissues and physiological conditions in older animals.

\section{CONCLUSIONS}

The age of slaughter influenced slightly the fatty acid profile and the nutritional indices (AI and TI) of the Leccese lamb meat. The meat of the older (60 days) lambs had a better sensory characteristics and consumer acceptability, showing an additional commercial value. These findings might be useful to characterise lamb meat of Leccese breed in relation to its nutritional traits and market perspectives.

\section{ACKNOWLEDGMENT}

This study was financially supported by the University of Bari. The authors wish to thank Mr. Di Santo for his assistance in animal management.

\section{REFERENCES}

[1] J. D. Wood, R. I.Richardson, G. R.Nute, A. V.Fisher, M. M.Campo, E. Kasapisou, P. R. Sheard, and M. Enser, "Effect of fatty acids on meat quality: a review," Meat Science, vol. 66, pp. 21-32, 2004.

[2] C. A. Daley, A. Abbott, P. S. Doyle, G. A. Nader, and S. Larson, "A review of fatty acid profiles and antioxidant content in grass-fed and grain-fed beef', Nutrition Journal, Vol. 9 (10), doi:10.1186/14752891-9-10, 2010
[3] S. De Smet, K. Raes, and D. Demeyer, "Meat fatty acid composition as affected by fatness and genetic factors: a review", Animal Research, vol. 53, pp. 81-89, 2004.

[4] M. Juárez, A. Horcada, M.J. Alcalde, M. Valera, O. Polvillo, and A Molina, "Meat and fat quality of unweaned lambs as affected by slaughter weight and breed", Meat Science, vol. 83, pp. $308-313$, 2009.

[5] A. G. D’Alessandro, M. Palazzo, K. Petrotos, P. Goulas, and G Martemucci, "Fatty acid composition of light lamb meat from Leccese and Comisana dairy breeds as affected by slaughter age", Small Ruminant Research, vol. 127, pp. 36-43, 2015

[6] J. Folch, M. Lees, and G. H. Slogane Stanley, "A simple method for isolation and purification of total lipids from animal tissues", The Journal of Biological Chemistry, vol. 226, pp. 497-509, 1957.

[7] T. L. V. Ulbricht, and D. A. T. Southgate, "Coronary heart disease: seven dietary factors", The Lancet, vol. 338, pp. 985-992, 1991.

[8] A. G. D'Alessandro, G. Maiorano, B. Kowaliszyn, P. Loiudice, and G. Martemucci, "How the nutritional value and consumer acceptability of suckling lamb meat is affected by the maternal feeding system". Small Ruminant Research, vol. 106, pp. 83-91, 2012

[9] SAS: "SAS/STAT 9.1 User's Guide Version" (9 Edition). Cary, NC: SAS Institute Incorporated, 2002

[10] M. J. Beriain, A. Horcada, A. Purroy, G. Lizaso, J. Chasco, and J. A Mendizabal, "Characteristics of Lacha and Rasa Aragonesa lambs slaughtered at three live weights" Journal of Animal Science, vol. 78, pp. 3070-3077, 2000 .

[11] D. Kritchevsky, "Conjugated linoleic acid in experimental atherosclerosis," Advances in Conjugated Linoleic Acid Research, vol. 2, J. Sebedio, W. W. Christie and R. Adolf, Eds., AOCS Press, Champaign, IL, pp. 291-301, 2003.

[12] M. A. Belury, "Conjugated linoleic acid in type 2 diabetes mellitus: implications and potential mechanisms" Advances in Conjugated Linoleic Acid Research, vol. 2, . J. Sebedio, W. W. Christie and R. Adolf, Eds., AOCS Press, Champaign, IL, pp. 302-315, 2003

[13] M. Philpott, and L. R. Ferguson, "Immunonutrition and cancer", Mutation Research, vol. 551, pp. 29-42, 2004

[14] J. M. Gaullier, J. Halse, H. O. Høivik, K. Høye, C. Syvertsen, M Nurminiemi, C. Hassfeld, A. Einerhand, M. O'Shea, and O. Gudmundsen, "Six months supplementation with conjugated linoleic acid induces regional-specific fat mass decreases in overweight and obese", British Journal of Nutrition, vol. 97, pp. 550-560, 2007.

[15] A. Dilzer, and Y. Park, "Implication of conjugated linoleic acid (CLA) in human health". Critical Review in Food Science and Nutrition, vol. 52, pp. 488-513, 2012.

[16] P. French, E. G. O'Riordan, F. J. Monahan, P. J. Caffrey, M. T. Mooney, D. J. Troy., and A. P. Moloney, "The eating quality of meat of steers fed grass and/or concentrates". Meat Science, vol. 75, pp. 379-386. 2001.

[17] S. Martinez-Cerezo, C. Sañudo, B. Panea, I. Medel, R. Delfa, I Sierra, J. A. Beltran, R. Cepero, J. L Olleta, "Breed, slaughter weight and ageing time effects on physicochemical characteristics of lamb meat". Meat Science, vol. 69, pp. 325-333. 2005.

[18] P. A. Tshabalala, P. E. Strydom, E. C. Webb, and H. L. de Kock, "Meat quality of designed South Africa indigenous goat and sheep breeds". Meat Science, vol. 64, pp. 563-570, 2003. 